\section{Inequality and the Urban-rural Divide in China: Effects of Regressive Taxation}

\author{
Xiaobing Wang, Jenifer Piesse*
}

\begin{abstract}
Using three comparable national representative household surveys for China in 1988, 1995 and 2002, the present paper reveals the regressivity and urban bias of China's direct tax and welfare system in this period. It shows that a regressive taxation system and skewed allocation of subsidies increases the urban-rural income gap and enhances overall inequality. Modeling these relationships indicates that the relatively poorer rural population has a net tax liability, whereas those in the richer urban areas receive net subsidies. This pattern is common in China, although the extent of the bias varies. This skewed system of tax and welfare payments is a major cause of the persisting urban-rural income gap and contributes to the overall income inequality in China. The abolishment of the agriculture tax in 2006 has had a positive impact on rural people's livelihoods.
\end{abstract}

K ey words: China, inequality, subsidies, taxation, urban-rural divide J E L codes: I38, K34, R11, R20

\section{Introduction}

China's GDP has grown significantly during the past three decades since economic reform commenced in 1978 and is maintained at approximately 10 percent per annum, on average. However, there is also increasing inequality, with the Gini coefficient rising from 0.33 in 1980 to 0.40 in 1994 and to 0.46 in 2000 (Chang, 2002). The urban-rural divide has also

\footnotetext{
* Xiaobing Wang, Lecturer. School of Social Science and Centre for Chinese Studies, University of Manchester, UK. Email: xiaobing.wang@manchester.ac.uk; Jenifer Piesse (corresponding author), Professor, Business School, Bournemouth University, UK. Email: jpiesse @bournemouth.ac.uk. The authors thank Shi Li for providing China Household Income Project data 2002, Jeremy Clegg, Xiaming Liu, Paul Ryan, Roger Strange, Nick Weaver, the Editor of this journal and the reviewers for their comments and suggestions. Piesse acknowledges the University of Stellenbosch's Over-arching Strategic Plan for funding that enabled this paper to be produced.
} 
increased. A gap between rural and urban incomes has existed in China since the establishment of the household registration (Hukou) system in 1955. According to Sicular et al. (2007), the urban-rural income gap, measured as the ratio of the average urban to rural per capital income, increased from 2.83 in 1995 to 3.01 in 2002. This gap is now one of the largest in the world and would be even greater if differences in standard of living, welfare benefits and infrastructure were taken into consideration.

Although there has been considerable interest in the published literature in the income gap and the urban-rural divide in China, few studies have explored the role that taxes and subsidies contribute to this inequality. Many papers attribute inequality to the dualistic economic structure (Griffin and Zhao, 1993), the economic transition and transformation (Knight and Song, 1999), market forces (Gao, 2006) and regional disparity (Gustafsson and $\mathrm{Li}, 1997)$. One exception is Tao and Liu (2005), who argue that one of the main reasons for the urban-rural income gap is the highly regressive system of taxation, where the rural poor pay a disproportionally higher share in the form of the agricultural tax. Although the incomes of rural households are much lower than those of their urban counterparts, rural households are taxed much more heavily.

The present study examines the impact of direct taxes and subsidies on the income gap in China between 1988 and 2002. Two related questions are discussed. First, over this period, how did the system of taxes and subsidies affect household incomes in rural and urban China? Second, has this system reduced or increased the overall urban-rural income gap and general inequality in China since economic reform began in 1978. Three national representative household surveys in 1988, 1995 and 2002 are used to identify household incomes, the tax burden and the distribution of subsidies. The major conclusions are: the tax system and provision of subsidies increase the urban-rural divide and overall inequality, and the status of the lower income class that exists in rural China is largely a direct result of the urban-rural segregation policy and the regressive tax system.

The present study contributes to the literature on inequality in China in three ways. First, this is one of the very few studies on the tax system and the first to analyze and decompose the impact of taxation and subsidies on the urban-rural income gap and overall inequality. Second, the present paper shows that the regressive tax system added an additional burden to extremely poor households and made it difficult for them to escape from poverty. This partly explains the persistence of the incidence of poverty in rural areas and the increasing urban-rural income gap. Third, it provides a rationale for the abolition of the agricultural tax and the associated fees and charges in 2006 because these had a negative impact on the welfare of the rural population.

The rest of the present paper is structured as follows. Section II reviews the literature on taxation, including the established models used to allocate the burden of taxation and 
the system of subsides, with special reference to China. Section III presents a data analysis. Models to link the pattern of taxes and subsides to the rise in income inequality are presented in Section IV, including the specification and results. Section V decomposes overall inequality into the effects between and within the urban and rural sectors and compares the changes before and after the transfer of income. Section VI concludes the paper.

\section{Literature Review}

\section{Theory of Taxation}

The design of a national system of taxation has consequences for prosperity and economic growth and also has a major impact on income distribution. Inappropriate taxation will distort the market, and can cause economic inefficiency and social injustice.

Economists traditionally use two approaches to evaluate how the tax burden should be allocated: the benefit principle and the ability-to-pay principle (Slemrod, 1994, 2006; Musgrave, 1994). Under the benefit principle, taxes are the contribution paid for receipt of services provided by the state. The ability-to-pay principle posits that the tax burden should be assigned not on the basis of who benefits from government provision, but rather who has the ability to pay. Mirrlees's (1971) paper on optimal taxation put the decision in a utilitarian framework: the tax burden should be assigned to maximize social welfare or efficiency. The entitlement basis for distributive justice was thereby replaced by utilitarian welfaremaximization.

The optimal system of taxation seeks to balance two objective functions: to raise tax revenue to achieve economic growth and to provide welfare (see Vickrey, 1947, 1992). The modern approach to evaluating tax progressivity focuses on the trade-off between the potential social benefits of a more equal distribution of income and the economic costs caused by the disincentive effects of the high marginal tax rate required by a redistributive tax system. In most developed countries, the social welfare system is a major means of income redistribution, although this varies depending on the national political climate. Two common non-progressive taxes are an ad valorem tax, such as a value-added tax (VAT) and a poll tax. A VAT is a direct consumption tax, which can have positive welfare effects, particularly if basic goods are excluded. Poll tax is universally unpopular in equity terms.

Subsidies have also been contentious. For example, the USA and the EU protect farmers and subsidize agriculture, whereas developing countries exploit their farmers to support industrial growth and subsidize urban residents (Lin et al., 1996).

An important feature of a tax system lies in whether tax should be proportional, progressive or regressive. Progressive taxes reduce the tax burden of people with low 
incomes, and increase tax for those with higher incomes, whereas regressive taxes have the opposite effect. However, there is virtually no discussion in the published literature on systems in which those on lower incomes pay more tax than those with higher incomes, while at the same time those with higher incomes receiving greater subsidies or social benefits. Examples of such an extreme regressive tax and subsidy system are rare. However, this existed in China during the reform period up to the end of 2005 and, to a large extent, it is responsible for the continued increase in the income gap and urban-rural disparity.

\section{Urban-rural Income Gap in China}

The urban-rural income gap has developed within the context of the Hukou system, which divided the population in China into two groups: those in the urban sector with the associated political and economic benefits and privileges, and those in the rural areas, generally with less political rights and few opportunities to participate in or influence policy. Every Chinese citizen was registered as a resident in a specific place and, particularly in the pre-reform era, this functioned as a de facto internal passport mechanism and migration could not change Hukou status. ${ }^{1}$ This resulted in differences in the lives and livelihoods of these two groups. Figure 1 shows the income and consumption gap between the urban and the rural population from 1978 to 2005. It is clear that the urban-rural income gap has been increasing over time with two exceptions. First, between 1978 and 1985 the income gap fell because of rural reform and the introduction of the Household Responsibility System, which ended collective farming

\section{Figure 1. Income and Expenditure Gaps of Urban and Rural} Households, 1978-2005 (nominal RMB)

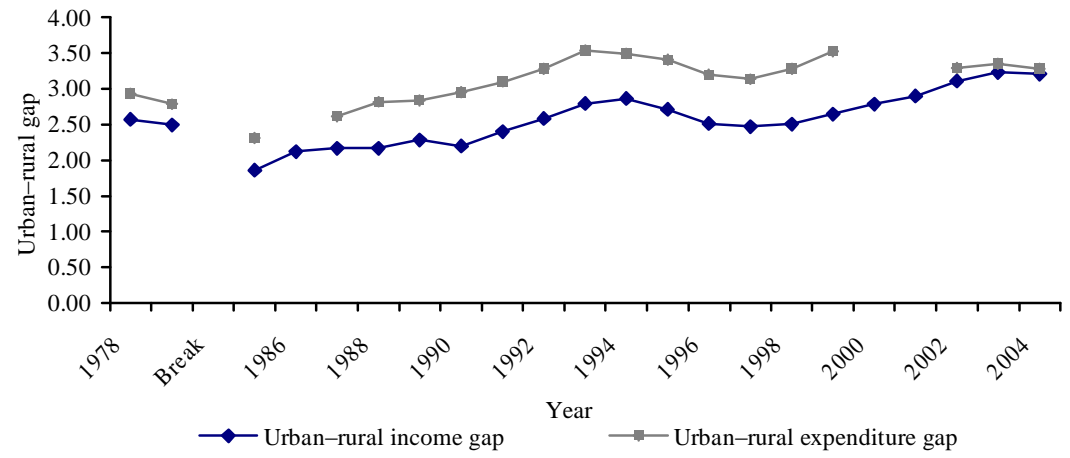

Source: Calculated by the authors based on the data from NBS (1978-2005).

N otes: Breaks occur where data are unavailable.

\footnotetext{
${ }^{1}$ In this paper, rural migrants are members of rural households for tax and subsidy proposes, although they are employed in the urban area.
} 
and reallocated land to individual households. Second, the income gap fell between 1994 and 1997 when many workers in the urban sector were unemployed. It is important to note that these calculations use only average household disposable income and capture a small amount of the difference in real well-being of individuals.

\section{System of Taxation and Subsidies in China}

In most developed countries, a system of progressive taxation exists based on incomes, and the revenue is used to provide benefits to the overall population. Depending on the political stance of governments, this system ensures some level of social justice. However, in China, although the rural population accounts for two-thirds of the total population, the system of taxes and subsidies has long favored the privileged urban class and exploited impoverished rural residents.

In China, two types of direct taxes were imposed on households during our sample period: an income tax and an agricultural tax. ${ }^{2}$ Income tax is payable when incomes exceed a certain threshold. Rural households were required to pay an agricultural tax according to their Hukou status, whereas urban residents did not pay these taxes as they are not involved in agricultural production.

The Individual Income Tax Law of the People's Republic of China was passed in 1980, with the tax threshold set at RMB800/month, 20 times higher than the average monthly wage at that time of RMB40. This did not change until 2006, when the tax threshold was increased to RMB1600/month, ${ }^{3}$ which was then approximately the average monthly wage in China. ${ }^{4}$ Urban residents rarely paid income tax in the 1980s and 1990s, either because their wages were below the threshold, or because of lack of enforcement of the Individual Income Tax Law. Indeed, if the tax threshold had been the same in both urban and rural sectors, few rural residents would have been liable. However, the inconsistency is that the agricultural tax liability facing the rural population was set at a flat rate, although this differed between provinces. ${ }^{5}$ The Agricultural Tax Regulations set the national average rate of 15.5 percent of the value of the yield in a normal year and, in most cases, was paid in kind. The tax on agricultural specialties was ad valorem and was between 5 and 25 percent. In addition, the rural population pays fees and administrative charges to the village and various levels of governments for social welfare, infrastructure and management and to the

\footnotetext{
${ }^{2}$ Residents also pay indirect taxes associated with the consumption of goods and services, but this paper focuses on direct tax only.

${ }^{3}$ This is according to the Individual Income Tax Law of the People's Republic of China (revised in 2005).

${ }^{4}$ This remains at a national level despite widely varying economic growth and prosperity across provinces.

${ }^{5}$ Literature on the rural tax system in China is sparse, but see Bernstein and Lu (2000) and Tao and Liu (2005). 
township for education, family planning, paramilitary support, infrastructure and irrigation. ${ }^{6}$ However, most of those services fail to materialize (Knight and Song, 1999).

An agricultural tax was first introduced in China around 600BC. However, since 1949, the state has relied heavily on indirect and direct taxation of agriculture, first to mobilize investment for industrialization (1949-1985), and later during the reform period (1985-1992) to ensure affordable food supplies and, therefore, social stability in the urban areas. Since the mid1990s, the rural tax burden has remained high to support the functions of local government (Lu and Wiemer, 2005). Overall, there have been hundreds of different kinds of taxes and fees imposed on farmers at various levels, despite some reforms aimed at lowering farmers' tax burden. From the introduction of agricultural tax up to 2006, at the national level, the share of agricultural tax to the total tax was decreasing, although the share of agricultural tax to added value of agriculture was increasing, making the tax burden in rural areas higher than before. The agricultural tax, which accounts for a small part of government revenue, is a large financial burden for farmers, whose incomes have growth only approximately 4 percent per year since 1996, a rate well below that of both urban residents and overall GDP (NBS, 2009).

Therefore, some reform has been implemented and the agricultural tax was abolished nationally in 2006, along with some of the local fees and administrative charges. In addition, farmers began to receive subsidies from 2004 (Chen, 2009) and the burden of rural residents has been considerably reduced. We will describe the data used for the analysis in the following section.

\section{Data}

To model this distortion it is necessary to take the tax burden and the degree of inequality into consideration. Because local governments differ across China, it is not possible to explain the tax burden facing individuals by simply using the tax rate imposed at the national level. Household surveys are required to obtain levels of income earned and tax paid. The survey data are used to examine the distribution of taxes and subsidies and to analyze their impact on household incomes.

\section{Sample}

The data are from three national household surveys: the Chinese Household Income Project

\footnotetext{
${ }^{6}$ Many studies, including Chen (2009), argue that farmers' burden are mainly from fees rather than a formal tax. Here both formal agriculture tax and various fees count as "tax" on farmers (see the data section for details).
} 
(CHIP) for 1988, 1995 and 2002. The data are drawn from a large-scale sample selected by the National Bureau of Statistics of China from the annual household survey (approximately 65000 rural and 35000 urban households), using a multistage, stratified probability sampling method. The CHIP 1988 dataset has 31827 urban and 51352 rural residents; the CHIP 1995 dataset includes 21694 urban and 34739 rural residents; and the CHIP 2002 dataset covers 20632 urban and 37968 rural residents plus 5318 migrants.

The CHIP study is the best publicly available data source on household income and expenditures and includes samples from provinces in the eastern, central and western regions of China (Riskin et al., 2001). For detailed analyses of the three surveys, see Griffin and Zhao (1993), Riskin et al. (2001) and Gustafsson et al. (2008).

\section{Included Items}

Urban (rural) households refer to those household members that have urban (rural) Hukou and have registered with the police as urban (rural) residents. Household income is cash payments and several additional components, such as payments in kind and agricultural output produced for self-consumption, both valued at market prices, the value of food and other direct subsidies, and the imputed value of housing services.

Total disposable household income is the sum of wages and salaries, net business income, income from property and transfers provided by members of the household, including income from various activities by members of households, but not from selling property or borrowed funds. The tax burden comprises formal agricultural taxes and various fees, including items such as surcharges, fees retained by villages and townships, ad hoc fees, and numerous contributions to fundraising paid by households in cash and in kind. There are also local fees in addition to those collected in compliance with state regulations.

\section{Data Description}

Figure 2 shows taxes and subsidies for (a) rural and (b) urban households in 1988. It is clear that rural households paid more taxes and received less subsidies at all income levels, whereas urban households paid no tax but received subsidies. There is also a distinct pattern illustrating the distortion that the subsidies received by urban residents were positively related to household income.

Figure 3 shows that urban residents received fewer subsidies in 1995 than in 1988, although the tax burden for rural households is not significantly changed. Figure 4 provides similar data for 2002. It is clear that reforms aimed at alleviating the rural tax burden were starting to take effect, and although rural households still had high tax liabilities, subsidies to this group also increased and the gap between total taxes paid and subsidies received 
Figure 2. Taxes and Subsidies as a Share of Income, 1988 (RMB): (a) Rural and (b) Urban

(a)

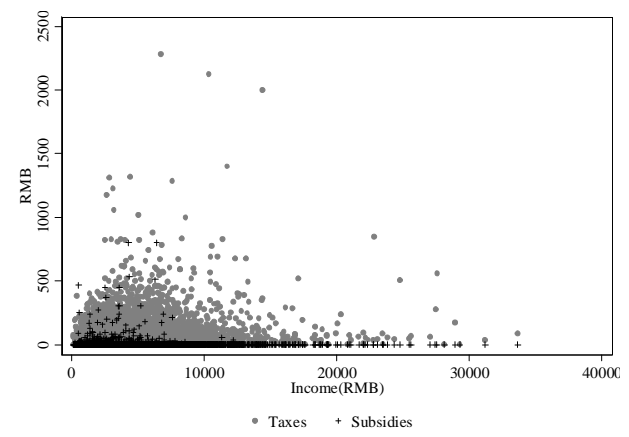

(b)

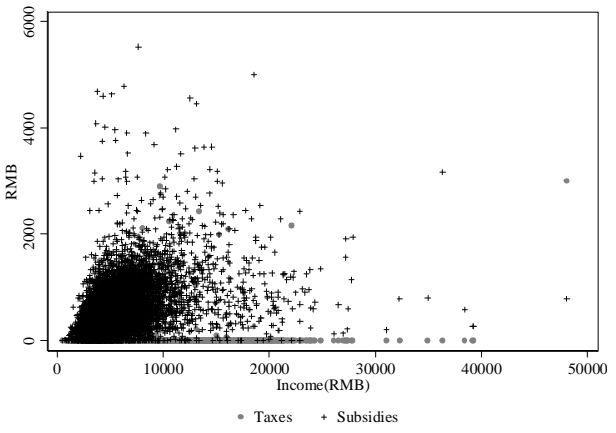

Figure 3. Taxes and Subsidies as a Share of Income, 1995: (a) Rural and (b) Urban

(a)

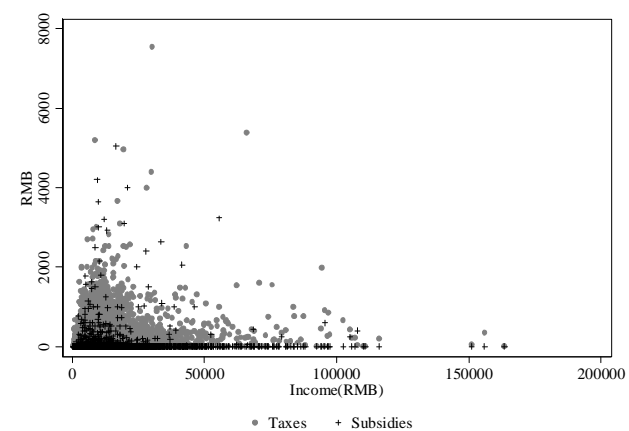

(b)

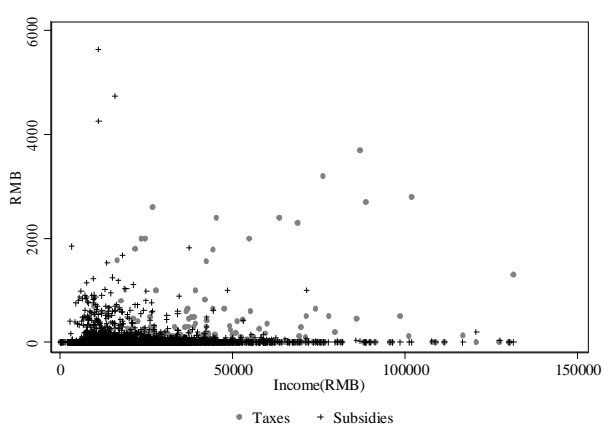

Figure 4. Taxes and Subsidies as a Share of Income, 2002: (a) Rural and (b) Urban

(a)

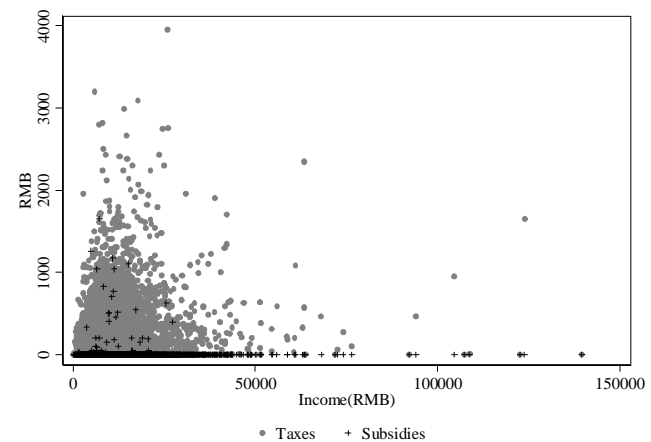

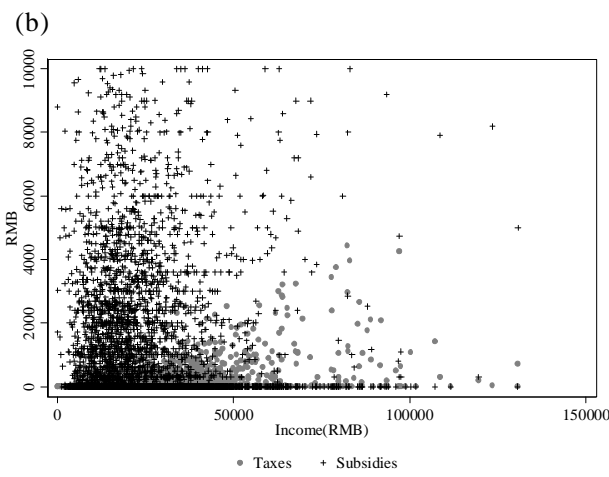

(C)2010 The Authors China \& World Economy (C2010 Institute of World Economics and Politics, Chinese Academy of Social Sciences 
was decreasing. Compared with 1988 and 1995, although urban households paid more tax and rural households received more support from the state or collectives, changes in the burden of taxation for rural households were still not evident.

For the purposes of comparison, the data are reordered to compare the level of the tax burden and subsidies received separately by rural and urban residents. Figure 5 shows the data for 1988. In Figure 5a, taxes are predominately paid by rural households and those with lower income in rural areas pay more tax than urban residents with higher income levels. Figure $5 \mathrm{~b}$ shows that the relatively richer urban residents received more subsidies than rural households. Data for 1995 (see Figure 6) and 2002 (see Figure 7) also show that those who living in rural areas paid significantly more tax than those living in urban areas, in both absolute and relative terms, and they received less support in terms of subsidies.

Figure 5. Tax Burdens and Subsidies Received by Region, 1988:

(a) Tax Burden and (b) Subsidies

(a)

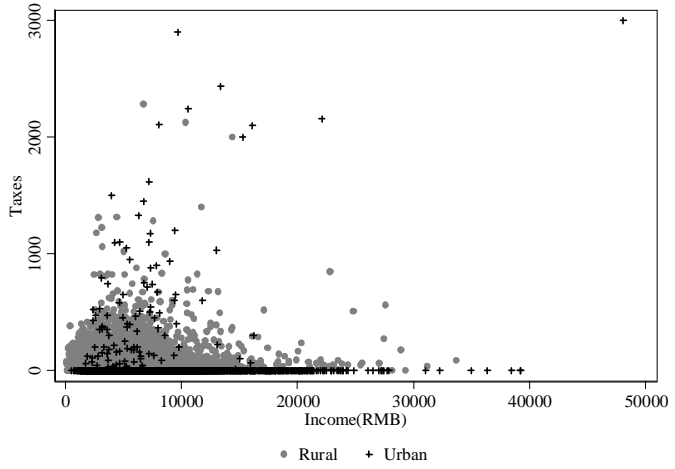

(b)

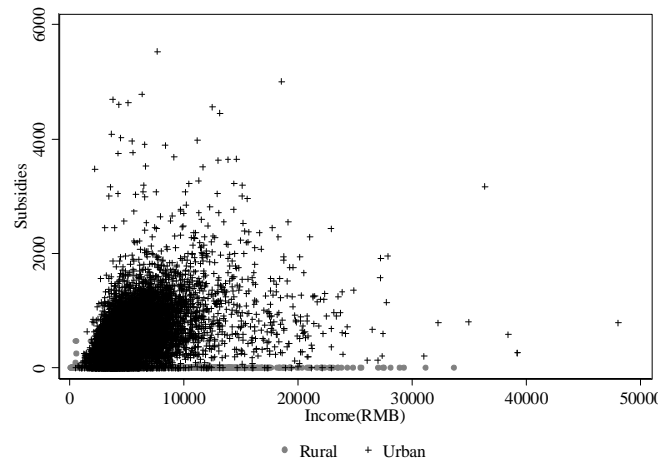

Figure 6. Tax Burdens and Subsidies Received by Region, 1995

(a)

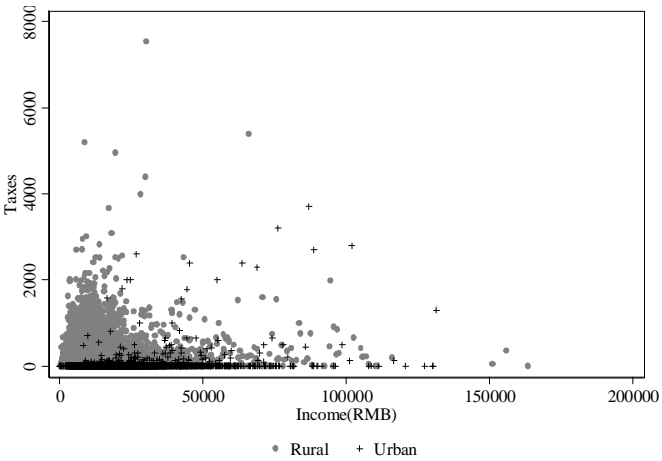

(b)

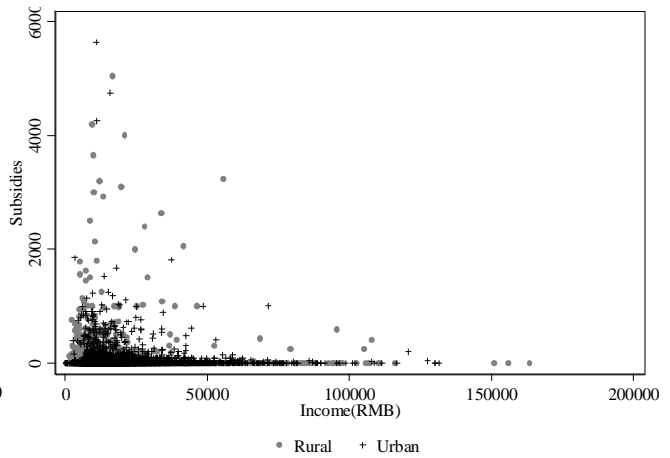

(C) 2010 The Authors

China \& World Economy (C2010 Institute of World Economics and Politics, Chinese Academy of Social Sciences 
Figure 7. Tax Burdens and Subsidies Received by Region, 2002

(a)

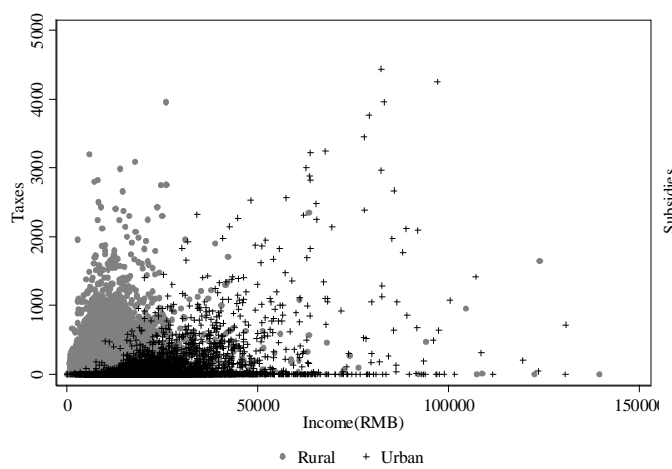

(b)

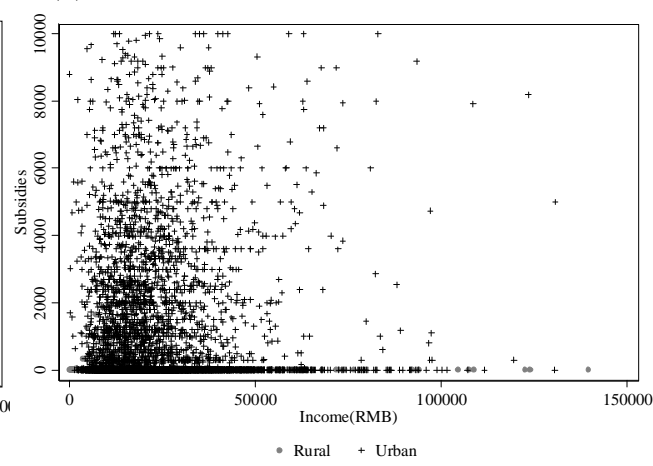

Table 1. Average Tax Rate by Income Decile for Rural Households

\begin{tabular}{c|c|c|c}
\hline Income decile (low to high) & $\mathbf{1 9 8 8}$ & $\mathbf{1 9 9 5}$ & $\mathbf{2 0 0 2}$ \\
\hline 1 & 13.7 & 13.7 & 8.9 \\
\hline 2 & 7.3 & 7.3 & 5.6 \\
\hline 3 & 5.6 & 5.6 & 4.7 \\
\hline 4 & 4.7 & 5.9 & 4.1 \\
\hline 5 & 4.2 & 5.8 & 3.6 \\
\hline 6 & 4.2 & 4.9 & 3.4 \\
\hline 7 & 3.5 & 4.7 & 3.1 \\
\hline 8 & 3.2 & 4 & 2.7 \\
\hline 9 & 2.9 & 2.8 & 2.1 \\
\hline 10 & 1.8 & 1.3 & 1.4 \\
\hline
\end{tabular}

Source: Constructed by authors.

N ote: Urban households are not included as they barely paid any income tax in the sample period.

To better understand the regressive nature of the tax burden in rural areas, rural households are divided into deciles according to their pre-tax income. The first column in Table 1 shows the income deciles from the bottom to the top, while other columns show the average tax rates for each decile of rural households. In 1988, the average tax rate for the first decile (the bottom 10 percent) of households is 13.7 percent, and for the tenth decile (the top 10 percent) is 1.8 percent. Looking at the ratio of these (13.7/1.8) we find that the tax burdens for households in the lowest decile are 7.6 times higher than for the highest income decile. The figures for this ratio for 1995 and 2002 are 10.5 and 6.4, respectively. This indicates that the tax system in rural areas has been regressive across the 3 years, although the figure for 2002 shows some improvement. These relationships are modeled in the next section. 


\section{Estimation}

\section{Model Specification}

The following specification is used with cross-section regressions, pooled across the provinces by year:

$$
\operatorname{Tax}_{i}=\alpha+\beta_{1} \text { Income }_{i}+\beta_{2} d_{i} \text { Income }_{i}+\sum \gamma_{i j} d_{i} g_{j}+\varepsilon_{i},
$$

where Tax is the tax and fees levied on household $i$, and Income is the income of household $i . d_{i}$ is the dummy variable equal to 1 if the household is rural and 0 otherwise. Therefore, when $d=0, \beta_{1}$ is the coefficient on urban incomes and when $d=1$, the coefficient for rural incomes is $\beta_{1}+\beta_{2}$. This dummy variable differentiates between urban and rural households and a provincial dummy $g$ controls for regional effects related to the $j$ provinces. ${ }^{7} \gamma_{i j}$ is the coefficient on the provincial dummy and $\varepsilon_{i}$ is the error term.

A similar expression is used to estimate the relationship between subsidies and incomes, with similar controls:

$$
\text { Subsidies }_{i}=\delta+\theta_{1} \text { Income }_{i}+\theta_{2} d_{i} \text { Income }_{i}+\sum \phi_{i j} d_{i} g_{j}+\varepsilon_{i} .
$$

In this case, if $\theta$ is positively related to income, it shows a systematic distribution of subsidies as a positive function of income. Again, controls for urban and rural households and a provincial dummy are included.

\section{Results}

(1) Taxes and Subsidies: 1988

Table 2 shows the estimated coefficients for Equations (1) and (2), in columns 1 and 2. Column 3 reports the results for net tax (taxes minus subsidies). For these three regressions, the specification is the same, with dummy variables for urban and rural households in 10 provinces and rural households in Gansu Province as the reference group. ${ }^{8}$ The coefficients for urban/rural household income indicate the tax rates for these two groups. The coefficients

\footnotetext{
${ }^{7}$ There is the possibility that income might be affected by taxes in competitive markets. When tax rates are high, individuals might choose to work longer to reach their desired standard of living and the income effect of taxes increases economic efficiency (Salanie, 2003). However, this endogeneity problem is unlikely to exist as China has high levels of surplus labor and the utility of leisure is very low. For many rural households close to subsistence, the marginal product of labor is zero. The substitution effect between work and leisure is not an issue. High tax burdens on the rural poor will lead to a reduction in livelihoods, while not increasing tax income and economic efficiency. Therefore, taxing the poor only has a redistribution effect that increases inequality.

${ }^{8}$ These 10 provinces are where data is available for both rural and urban households in 1988,1995 and 2002. 
Table 2. Comparison of Taxes and Subsidies in Urban and Rural China by Province, 1988

\begin{tabular}{|c|c|c|c|}
\hline D ependent variable & Taxes & Subsidies & Net tax \\
\hline \multirow[t]{2}{*}{ Income (urban) } & -0.000102 & 0.067207 & -0.067309 \\
\hline & $(0.00)$ & $(0.00)^{* * *}$ & $(0.00)^{* * * *}$ \\
\hline \multirow[t]{2}{*}{ Income (rural) } & 0.006953 & -0.067591 & 0.074544 \\
\hline & $(0.00)^{* * *}$ & $(0.00)^{* * * *}$ & $(0.00)^{* * * *}$ \\
\hline \multirow[t]{2}{*}{ Beijing (urban) } & -37.95 & 432.99 & -470.94 \\
\hline & $(3.55)^{* * *}$ & $(16.10)^{* * *}$ & $(16.50) * * *$ \\
\hline \multirow[t]{2}{*}{ Beijing (rural) } & -36.653 & 8.729 & -45.382 \\
\hline & $(6.20)^{* * *}$ & $(28.16)$ & $(28.72)$ \\
\hline \multirow[t]{2}{*}{ Shanxi (urban) } & -38.034 & 286.805 & -324.839 \\
\hline & $(2.79)^{* * *}$ & $(12.67)^{* * *}$ & $(12.98) * * *$ \\
\hline \multirow[t]{2}{*}{ Shanxi (rural) } & -3.659 & -2.459 & -1.200 \\
\hline & (3.36) & $(15.37)$ & $(15.00)$ \\
\hline \multirow[t]{2}{*}{ Liaoning (urban) } & -38.007 & 521.273 & -559.280 \\
\hline & $(2.89)^{* * *}$ & $(13.11)^{* * *}$ & $(13.43) * * *$ \\
\hline \multirow[t]{2}{*}{ Liaoning (rural) } & 7.451 & -2.461 & 9.911 \\
\hline & $(3.67)^{* *}$ & $(16.41)$ & $(17.09)$ \\
\hline \multirow[t]{2}{*}{ Jiangsu (urban) } & -38.004 & 301.184 & -339.187 \\
\hline & $(2.72)^{* * * *}$ & $(12.34) * * *$ & $(12.65) * * *$ \\
\hline \multirow[t]{2}{*}{ Jiangsu (rural) } & 6.402 & -2.425 & 8.827 \\
\hline & $(2.87)^{* * *}$ & $(12.76)$ & $(13.37)$ \\
\hline \multirow[t]{2}{*}{ Anhui (urban) } & -38.025 & 323.632 & -361.657 \\
\hline & $(2.92)^{* * *}$ & $(13.24)^{* * *}$ & $(13.56)^{* * *}$ \\
\hline \multirow[t]{2}{*}{ Anhui (rural) } & 46.009 & -2.349 & 48.359 \\
\hline & $(2.85)^{* * *}$ & $(13.05)$ & $(13.21)^{* * *}$ \\
\hline \multirow[t]{2}{*}{ Henan (urban) } & -38.031 & 166.993 & -205.024 \\
\hline & $(2.74)^{* * * *}$ & $(12.43)^{* * * *}$ & $(12.73)^{* * *}$ \\
\hline \multirow[t]{2}{*}{ Henan (rural) } & 20.314 & -2.849 & 23.162 \\
\hline & $(2.56)^{* * * *}$ & $(11.40)$ & $(11.88)^{*}$ \\
\hline \multirow[t]{2}{*}{ Hubei (urban) } & -38.033 & 345.025 & -383.058 \\
\hline & $(2.76)^{* * *}$ & $(12.52) * * *$ & $(12.83)^{* * * *}$ \\
\hline \multirow[t]{2}{*}{ Hubei (rural) } & 82.307 & -2.239 & 84.547 \\
\hline & $(2.85)^{* * *}$ & $(13.17)$ & $(13.21)^{* * *}$ \\
\hline \multirow[t]{2}{*}{ Guangdong (urban) } & -37.82 & 502.346 & -540.165 \\
\hline & $(3.33)^{* * *}$ & $(15.09)^{* * * *}$ & $(15.46)^{* * *}$ \\
\hline \multirow{2}{*}{ Guangdong (rural) } & 28.491 & -1.590 & 30.081 \\
\hline & $(3.37) * * *$ & $(15.90)$ & $(15.67)^{*}$ \\
\hline \multirow[t]{2}{*}{ Sichuan (urban) } & -38.053 & 340.322 & -378.376 \\
\hline & $(60.40)$ & $(276.68)$ & $(282.37)$ \\
\hline \multirow[t]{2}{*}{ Sichuan (rural) } & 5.787 & -2.002 & 7.789 \\
\hline & $(2.30)^{* *}$ & $(10.54)$ & $(10.67)$ \\
\hline \multirow[t]{2}{*}{ Yunnan (urban) } & -36.818 & 431.900 & -468.719 \\
\hline & $(2.86)^{* * *}$ & $(12.95)^{* * *}$ & $(13.27)^{* * *}$ \\
\hline Yunnan (rural) & -22.585 & -0.704 & -21.881 \\
\hline & $(3.37)^{* * * *}$ & (14.08) & $(15.63)$ \\
\hline Gansu (urban) & -38.007 & 456.365 & -494.372 \\
\hline & $(3.25)^{* * * *}$ & $(14.73)^{* * *}$ & $(15.09) * * *$ \\
\hline Gansu (rural) & Reference group & Reference group & Reference group \\
\hline Constant & 38.400 & 4.016 & 34.385 \\
\hline & $(1.33)^{* * *}$ & $(5.99)$ & $(6.18)^{* * *}$ \\
\hline Observations & 18887 & 18887 & 18887 \\
\hline Adjusted $R^{2}$ & 0.3013 & 0.6013 & 0.6344 \\
\hline
\end{tabular}

N otes: Standard errors are in parentheses. $* * *, * *$ and $*$ represent significance at 1,5 and 10 -percent levels, respectively.

for all the dummy variables adjust the intercepts with the constant; that is, the reference group. 
In column 1 of Table 2, the coefficient of rural income is positive and significant at the 1-percent level, but small (0.006953). This indicates that the sensitivity of the tax burden on income is negligible; that is, close to a flat rate of tax. This suggests that tax revenues increase by RMB7 when incomes increase by RMB1000 for rural households and that the tax system in rural China at that time was a flat tax, based on land allocation, or the size of the household, regardless of income.

There are two points worth noting. First, the coefficient of urban income is negative but not significantly different from zero, implying that there is no correlation between income and tax. Second, the impact on urban households in each province is close to zero, measured by the coefficient on the control variable plus the intercept. These joint effects make it clear that urban residents paid no tax.

The interpretation with respect to the dummy variable on rural households in each province is that all pay taxes, determined by the sum of the rural province number and the intercept in Table 2, although there are large spatial differences across provinces in the mean tax paid. The highest taxes per household were paid in Hubei Province, which is largely rural. Residents paid, on average, RMB120 more than rural households in Beijing (the rural income dummy in Hubei is 82.307 plus the intercept in Table 2 of 38.4. However, in Beijing, there is little difference between the level of urban and rural tax paid.

In column 2 of Table 2, it is shown that rural households received no subsides (the rural dummy plus the intercept and most of the coefficients are not significantly different from zero). However, urban residents received large subsidies, with the lowest amount per household in Shanxi (RMB286) and the highest in Liaoning and Guangdong (more than RMB500). Column 3 of Table 2 reports results for net tax, where a negative value is interpreted as a subsidy. Rural households paid positive net tax and urban households enjoyed negative net tax in all provinces. The fit for these regressions is very high for a cross-section model, with an adjusted $R^{2}$ of 30, 60 and 63 percent for taxes, subsidies and net tax, respectively. As noted above, within rural areas, taxation is slightly progressive: 0.006953 in column 1 and in column 2 the coefficient of urban income is 0.0672 , suggesting that subsidies are slightly regressive for urban residents.

\section{(2) Taxes and Subsidies: 1995}

Table 3 reports total taxes paid, subsidies received and net taxes paid by rural and urban residents in 10 provinces in 1995 . In column 1 , the coefficient of urban household income is 0.001968 , which is small but positive and significant, indicating a marginally progressive tax regime. The coefficient of rural households is 0.003977 , suggesting higher progressivity than in the urban areas. The key points of Table 3 are the coefficients of the dummy variables on rural and urban in each province. The estimated value of the urban dummy 
cancels out the intercept, indicating that zero taxes were paid. However, for the rural dummies in all provinces, positive taxes were paid. Clearly, large variations between the provinces still existed in 1995. There are conflicting results in column 2 (subsidies) and column 3 (net tax), and the adjusted $R^{2}$ for the subsidies model indicates low explanatory power. This means that the allocation principle for subsidies in 1995 is not based on income but other

\section{Table 3. Comparison of Taxes and Subsidies in Urban and Rural China by Province, 1995}

\begin{tabular}{|c|c|c|c|}
\hline D ependent variable & Taxes & Subsidies & $\mathrm{N}$ et tax \\
\hline \multirow[t]{2}{*}{ Income (urban) } & 0.001968 & -0.000195 & 0.002163 \\
\hline & $(0.00)^{\text {**** }}$ & $(0.00)$ & $(0.00)^{* * *}$ \\
\hline \multirow[t]{2}{*}{ Income (rural) } & 0.003977 & 0.00151 & 0.002467 \\
\hline & $(0.00)^{\text {**** }}$ & $(0.00)^{* * *}$ & $(0.00)^{* * *}$ \\
\hline \multirow[t]{2}{*}{ Beijing (urban) } & -250.622 & 88.903 & -339.525 \\
\hline & $(13.99) * * *$ & $(6.95) * * *$ & $(15.62) * * *$ \\
\hline \multirow[t]{2}{*}{ Beijing (rural) } & -285.361 & 40.318 & -325.679 \\
\hline & $(23.39) * * *$ & (11.62)*** & $(26.14) * * *$ \\
\hline \multirow[t]{2}{*}{ Shanxi (urban) } & -253.366 & 4.077 & -257.443 \\
\hline & $(11.12)^{* * *}$ & $(5.51)$ & $(12.42) * * *$ \\
\hline \multirow[t]{2}{*}{ Shanxi (rural) } & -91.071 & -4.273 & -86.799 \\
\hline & $(13.65)^{* * * *}$ & $(6.78)$ & $(15.25) * * *$ \\
\hline \multirow[t]{2}{*}{ Liaoning (urban) } & -263.138 & 16.878 & -280.016 \\
\hline & $(11.30)^{* * *}$ & $(5.61)^{* * *}$ & $(12.62) * * *$ \\
\hline \multirow[t]{2}{*}{ Liaoning (rural) } & -12.962 & 11.872 & -24.834 \\
\hline & $(13.50)$ & $(6.71)^{*}$ & $(15.05)^{*}$ \\
\hline \multirow[t]{2}{*}{ Jiangsu (urban) } & -263.992 & 6.968 & -270.960 \\
\hline & $(11.56)^{* * *}$ & $(5.76)$ & $(12.92) * * *$ \\
\hline \multirow[t]{2}{*}{ Jiangsu (rural) } & -96.310 & -10.262 & 86.048 \\
\hline & $(11.01)^{* * * *}$ & $(5.46)^{*}$ & $(12.29) * * *$ \\
\hline \multirow[t]{2}{*}{ Anhui (urban) } & -257.743 & 11.063 & -268.806 \\
\hline & $(12.27) * * *$ & $(6.08)^{*}$ & $(13.71) * * *$ \\
\hline \multirow[t]{2}{*}{ Anhui (rural) } & 79.722 & 15.194 & 64.528 \\
\hline & $(11.28) * * *$ & $(5.61)^{* * *}$ & $(12.60) * * *$ \\
\hline \multirow[t]{2}{*}{ Henan (urban) } & -254.763 & 3.369 & -258.132 \\
\hline & $(11.42) * * *$ & $(5.71)$ & $(12.76)^{* * * *}$ \\
\hline \multirow[t]{2}{*}{ Henan (rural) } & 43.318 & 0.650 & 43.969 \\
\hline & $(9.36)^{* * * *}$ & $(4.64)$ & $(10.44) * * *$ \\
\hline \multirow[t]{2}{*}{ Hubei (urban) } & -262.859 & 9.055 & 271.914 \\
\hline & $(11.21) * * *$ & $(5.56)$ & $(12.53)^{* * *}$ \\
\hline \multirow[t]{2}{*}{ Hubei (rural) } & 336.058 & 26.052 & 310.005 \\
\hline & $(11.86) * * *$ & $(5.89)^{* * *}$ & $(13.25) * * *$ \\
\hline \multirow[t]{2}{*}{ Guangdong (urban) } & -255.399 & 18.195 & -273.595 \\
\hline & $(15.40) * * *$ & $(7.64)^{* *}$ & $(17.21)^{* * * *}$ \\
\hline \multirow[t]{2}{*}{ Guangdong (rural) } & -133.780 & -3.045 & -130.735 \\
\hline & $(11.51)^{* * *}$ & $(5.75)$ & $(12.85)^{* * *}$ \\
\hline \multirow[t]{2}{*}{ Sichuan (urban) } & -262.612 & 4.301 & -266.914 \\
\hline & $(10.68)^{* * * *}$ & $(5.31)$ & $(11.93) * * *$ \\
\hline \multirow[t]{2}{*}{ Sichuan (rural) } & -3.191 & -1.381 & -1.81 \\
\hline & $(8.86)$ & $(4.45)$ & $(10.06)$ \\
\hline \multirow[t]{2}{*}{ Yunnan (urban) } & -255.961 & 31.066 & 287.027 \\
\hline & $(11.53) * * *$ & $(5.73)^{* * * *}$ & $(12.88)^{* * * *}$ \\
\hline Yunnan (rural) & -177.776 & 3.208 & -174.568 \\
\hline & $(13.57) * * *$ & $(6.68)$ & $(15.15)^{* * * *}$ \\
\hline Gansu (urban) & -256.333 & 117.184 & -373.516 \\
\hline & $(13.01)^{* * * *}$ & $(6.46)^{* * *}$ & $(14.54) * * *$ \\
\hline Gansu (rural) & Reference group & Reference group & Reference group \\
\hline Constant & 238.927 & 0.037 & 238.890 \\
\hline & $(5.00)^{* * * *}$ & $(3.70)$ & $(5.58)^{* * * *}$ \\
\hline Observations & 14761 & 14761 & 14761 \\
\hline Adjusted $R^{2}$ & 0.3312 & 0.0425 & 0.2898 \\
\hline
\end{tabular}

N otes: Standard errors are in parentheses. $* * *, * *$ and $*$ represent significance at 1,5 and 10 -percent levels, respectively. 
factors. For example, when reform deepened in the late 1990s, the amount of subsidy an individual received was increasingly based on their employer and location. Subsidies appear to be random with respect to income in the urban-rural framework.

(3) Taxes and Subsidies: 2002

Table 4. Comparison of Taxes and Subsidies in Urban and Rural China by Provinces, 2002

\begin{tabular}{|c|c|c|c|}
\hline D ependent variable & Taxes & Subsidies & N et tax \\
\hline \multirow[t]{2}{*}{ Income (urban) } & 0.009465 & 0.011175 & -0.00171 \\
\hline & $(0.00)^{* * *}$ & $(0.00)^{* * *}$ & $(0.00)$ \\
\hline \multirow[t]{2}{*}{ Income (rural) } & 0.072359 & 0.001647 & 0.066433 \\
\hline & $(0.00)^{* * *}$ & $(0.00)$ & $(0.01)^{* * *}$ \\
\hline \multirow[t]{2}{*}{ Beijing (urban) } & 22.424 & 1676.240 & -1672.706 \\
\hline & $(70.08)$ & $(200.51)^{* * *}$ & $(247.44)^{* * *}$ \\
\hline \multirow[t]{2}{*}{ Beijing (rural) } & 193.482 & 112.849 & 341.938 \\
\hline & $(84.49)^{* *}$ & $(240.10)$ & $(313.70)$ \\
\hline \multirow[t]{2}{*}{ Shanxi (urban) } & 132.505 & 266.840 & -153.221 \\
\hline & $(62.21)^{* *}$ & (177.89) & (228.69) \\
\hline \multirow[t]{2}{*}{ Shanxi (rural) } & 343.394 & 102.775 & 332.563 \\
\hline & $(64.55) * * *$ & $(183.53)$ & $(246.34)$ \\
\hline \multirow[t]{2}{*}{ Liaoning (urban) } & 143.444 & 545.094 & -420.535 \\
\hline & $(62.10)^{* *}$ & $(177.56)^{* * *}$ & $(226.09)^{*}$ \\
\hline \multirow[t]{2}{*}{ Liaoning (rural) } & 828.178 & 5.472 & 827.798 \\
\hline & $(62.98) * * *$ & $(182.40)$ & $(257.88)^{* * *}$ \\
\hline \multirow[t]{2}{*}{ Jiangsu (urban) } & 101.090 & 862.573 & -780.368 \\
\hline & $(62.02)$ & $(177.85)^{* * * *}$ & $(226.85)^{* * * *}$ \\
\hline \multirow[t]{2}{*}{ Jiangsu (rural) } & 461.247 & 474.545 & -16.964 \\
\hline & $(64.69) * * *$ & $(185.37)^{* * *}$ & $(242.34)$ \\
\hline \multirow[t]{2}{*}{ Anhui (urban) } & 178.655 & 373.689 & -213.920 \\
\hline & $(64.73) * * *$ & $(184.99)^{* * *}$ & $(232.52)$ \\
\hline \multirow[t]{2}{*}{ Anhui (rural) } & 125.289 & 23.166 & 86.962 \\
\hline & $(63.28)^{* * *}$ & $(178.20)$ & (248.46) \\
\hline \multirow{2}{*}{ Henan (urban) } & 140.123 & 107.685 & 13.552 \\
\hline & $(61.46)^{* *}$ & (176.53) & (225.87) \\
\hline \multirow[t]{2}{*}{ Henan (rural) } & 41.804 & 15.222 & 49.249 \\
\hline & $(60.59)$ & (169.13) & (223.86) \\
\hline \multirow[t]{2}{*}{ Hubei (urban) } & 151.707 & 762.848 & -630.026 \\
\hline & $(61.92)^{* * *}$ & $(176.99)^{* * * *}$ & $(225.82)^{* * * *}$ \\
\hline \multirow[t]{2}{*}{ Hubei (rural) } & 466.709 & 114.154 & 190.594 \\
\hline & $(61.25)^{* * * *}$ & $(175.62)$ & $(241.26)$ \\
\hline \multirow[t]{2}{*}{ Guangdong (urban) } & 200.685 & 2762.550 & -2580.750 \\
\hline & $(68.26)^{* * *}$ & $(195.37)^{* * * *}$ & $(242.55)^{* * * *}$ \\
\hline \multirow[t]{2}{*}{ Guangdong (rural) } & -162.558 & 333.963 & -425.546 \\
\hline & $(64.25)^{* *}$ & $(183.50)^{*}$ & $(233.82)^{*}$ \\
\hline \multirow[t]{2}{*}{ Sichuan (urban) } & 119.465 & 416.669 & -316.090 \\
\hline & $(62.88)^{*}$ & $(180.38)^{* *}$ & (229.05) \\
\hline Sichuan (rural) & 165.028 & 152.311 & 27.924 \\
\hline & $(61.58) * * *$ & (175.07) & (232.70) \\
\hline Chongqing (urban) & 124.253 & 862.627 & -757.260 \\
\hline & $(73.52)^{*}$ & $(210.40)^{* * *}$ & $(256.70)^{* * *}$ \\
\hline Chongqing (rural) & 250.983 & 31.370 & 235.787 \\
\hline & $(77.46)^{* * *}$ & $(224.07)$ & $(267.94)$ \\
\hline Yunnan (urban) & 122.142 & 1346.840 & -1243.588 \\
\hline & $(62.64)^{*}$ & $(178.63)^{* * * *}$ & $(227.35)^{* * *}$ \\
\hline Yunnan (rural) & 127.357 & 79.665 & 4.557 \\
\hline & $(71.55)^{*}$ & $(204.27)$ & $(227.85)$ \\
\hline Gansu (urban) & 142.190 & 1586.040 & -1462.740 \\
\hline & $(67.39)^{* *}$ & $(192.48)^{* * * *}$ & $(239.79)^{* * *}$ \\
\hline Gansu (rural) & Reference group & Reference group & Reference group \\
\hline Constant & -273.210 & 28.141 & -282.465 \\
\hline & $(49.58)^{* * *}$ & $(140.71)$ & (196.16) \\
\hline Observations & 11545 & 11545 & 10589 \\
\hline Adjusted $R^{2}$ & 0.2993 & 0.0909 & 0.1389 \\
\hline
\end{tabular}

(C) 2010 The Authors

China \& World Economy (C2010 Institute of World Economics and Politics, Chinese Academy of Social Sciences 
Notes: Standard errors are in parentheses. $* * *, * *$ and $*$ represent significance at 1,5 and 10-percent levels, respectively.

Table 4 reports results for 2002. In column 1, the coefficient on rural household income is 0.072359 and for urban household income is 0.009465 , showing that rural households had a higher tax burden. In column 2, the subsidies model has a coefficient on urban households of 0.011175 and for rural households 0.001647 , although this is not significantly different from zero. This suggests that urban households still received subsidies under a progressive system while those for rural households are were related to income. In column 3, the coefficient on urban household income is negative but insignificant, as expected. The coefficient on rural households is significant, meaning that this group still had a positive net tax liability. Examining the dummy variables on rural and urban income in each province, rural households paid more tax than urban households (see column 1), and most rural dummy variables are not significantly different from zero (see column 2 ). The adjusted $R^{2}$ indicates a higher goodness of fit in the taxation model (0.2993), but there is lower explanatory power in the subsidies model, reflecting the small subsidies to rural households.

\section{(4) Trends}

By observing the tax burden on rural households and the subsidies received by urban households during the sample period, we can determine the impact of policy change over 1998-2002. In particular, it is interesting to identify whether there has been any reduction in the urban-rural income gap. Three trends are of interest.

First, most urban residents now face some degree of tax liability, while some rural households have begun to receive subsidies. In 1988, almost no tax was paid by urban residents, but the number of urban residents paying tax and the amount of tax they paid as a share of income had increased by 2002. Furthermore, rural households that received no financial support in 1988 started to receive some subsidies in 2002.

Second, in the urban sector, the structure of the tax burden has become slightly more progressive from the high levels of regressivity in the past. For this group, the coefficient has changed from negative in 1988(-0.000102) to positivein 1995 (0.001968) and in 2002(0.009465). These values are still small, but growing, indicating that China is moving toward a fairer tax system.

Third, subsidies have started to play a role in helping households at the lower end of the income distribution move out of extreme poverty. Households in the lowest pre-tax pretransfer income decile received some support in the form of subsidies after 1995. Although this is directed mostly toward the urban poor, this is a positive step in redistribution and reversing the earlier inequality. 


\section{Decompositions and Comparisons of the Tax Burden in Urban and Rural China}

After finding the presence of strong regressivity of direct taxes in China, this section investigates the impact on the urban-rural income gap and overall inequality using generalized entropy indices. ${ }^{9}$ This section decomposes inequality by urban and rural households using the Theil L (mean logarithmic deviation, or GE(0)) and Theil T (GE(1)) entropy measures (see Shorrocks (1984) and Shorrocks and Wan (2005) for a discussion). This allows a separation of the overall inequality to the weighted sum of inequality within urban and rural sectors, and the inequality measured across mean incomes of urban and rural households (Sicular et al., 2007). The Theil L is defined as follows:

$$
I_{T L}=\frac{1}{n} \sum_{i=1}^{n} \ln \left(\frac{\mu}{y_{i}}\right),
$$

and the Theil $\mathrm{T}$ can be expressed as:

$$
I_{T T}=\frac{1}{n} \sum_{i=1}^{n}\left(\frac{y_{i}}{\mu}\right)\left[\ln \left(\frac{y_{i}}{\mu}\right)\right],
$$

where $\mu$ is the mean income, $y_{i}$ stands for income of the $i$ th individual and $n$ is the total number of individuals.

Theil $\mathrm{L}$ and Theil $\mathrm{T}$ can be decomposed among subgroups such as urban and rural populations:

$$
I=I_{\text {Within }}+I_{\text {Between }}=\sum_{g=1}^{k} w_{g} I_{g}+I\left(\mu_{1}, \mu_{2}, \ldots, \mu_{k}\right),
$$

where $w_{g}$ is a weight attached to the $g$ th group, $I_{g}$ inequality within the $g$ th group, and $\mu_{g}$ mean income of the $g$ th group.

When the subgroups are urban and rural, this becomes:

$$
I=I_{\text {Within }}+I_{\text {Between }}=w_{\text {urban }} I_{\text {urban }}+w_{\text {rural }} I_{\text {rural }}+I\left(\mu_{\text {urban }}, \mu_{\text {rural }}\right),
$$

where $w_{\text {urban }} I_{\text {urban }}$ is a weighted inequality within urban areas, $w_{\text {rural }} I_{\text {rural }}$ a weighted inequality within rural areas and $I\left(\mu_{\text {urban }}, \mu_{\text {rural }}\right)$ the inequality between urban and rural areas.

\footnotetext{
9 The Gini coefficient has many desirable properties (e.g. mean independence, population size independence, symmetry and Pigou-Dalton transfer sensitivity), but does not allow decomposition of the population into subgroups, such as urban and rural to examine within-group and between-group inequality.

(C) 2010 The Authors

China \& World Economy (C2010 Institute of World Economics and Politics, Chinese Academy of Social Sciences
} 
Table 5. Inequality Decomposition by Urban and Rural Households, before and after Taxes and Subsidies

\begin{tabular}{|c|c|c|c|c|c|c|c|c|c|c|c|c|}
\hline & \multicolumn{4}{|c|}{1988} & \multicolumn{4}{|c|}{1995} & \multicolumn{4}{|c|}{2002} \\
\hline & \multicolumn{2}{|c|}{ Theil L } & \multicolumn{2}{|c|}{ Theil T } & \multicolumn{2}{|c|}{ Theil L } & \multicolumn{2}{|c|}{ Theil T } & \multicolumn{2}{|c|}{ Theil L } & \multicolumn{2}{|c|}{ Theil T } \\
\hline & Before & After & Before & After & Before & After & Before & After & Before & After & Before & After \\
\hline Total & 0.16480 & 0.18514 & 0.16279 & 0.17478 & 0.27183 & 0.28243 & 0.31214 & 0.32034 & 0.23154 & 0.24337 & 0.22031 & 0.23012 \\
\hline Between & 0.01881 & 0.03425 & 0.01872 & 0.03384 & 0.03741 & 0.04120 & 0.03697 & 0.04063 & 0.04903 & 0.06042 & 0.04565 & 0.05560 \\
\hline Within & 0.14599 & 0.15089 & 0.14407 & 0.14094 & 0.23442 & 0.24123 & 0.27517 & 0.27971 & 0.18251 & 0.18295 & 0.17466 & 0.17452 \\
\hline \multicolumn{13}{|c|}{ Contribution of between and within effects (\%) } \\
\hline Total & 100.00 & 100.00 & 100.00 & 100.00 & 100.00 & 100.00 & 100.00 & 100.00 & 100.00 & 100.00 & 100.00 & 100.00 \\
\hline Betwe & & & 11.50 & 19.36 & 13.76 & 14.59 & 11.84 & 12.68 & 21.18 & 24.83 & 20.72 & 24.16 \\
\hline Within & 88.59 & 81.50 & 88.50 & 80.64 & 86.24 & 85.41 & 88.16 & 87.32 & 78.82 & 75.17 & 79.28 & 75.84 \\
\hline
\end{tabular}

Notes: Between and within refer to the effects between urban and rural groups, and within rural and urban groups, respectively.

Table 5 reports the two Theil indices and the inequality decompositions using income before and after taxes and subsidies in each year. By comparing these inequality indices the impact of taxes on overall inequality and each component of inequality can be determined.

From Table 5, there are two interesting results. First, taxes and subsidies increase the urban-rural income gap and contribute to overall inequality. For example, in 1988, the Theil L indices increase from 0.165 before tax and subsidies change to 0.185 after the transfer of income. This increases the urban-rural income gap as the contribution to overall inequality increases from 11.41 to 18.50 percent. Second, taxes and subsidies increase overall inequality in China over the period from 1988 to 2002, confirming the results of the estimation. For example, the share of between effects for Theil L increases from 18.50 percent in 1988 to 24.83 percent in 2002 , indicating a clear increase in inequality caused by tax.

\section{Conclusions and Welfare Implications}

The increase in inequality in China has been pronounced over the past two decades. Understanding the causes and trends of the rural-urban income gap is important for improving social welfare and maintaining political stability. The heavy industry-oriented development strategy has been supported by exploiting rural agriculture, which has been the case in many developing countries, such as China. This results in different taxation regimes and a diverse set of social support systems for rural and urban populations. The situation has been exacerbated by institutional barriers that restrict labor mobility.

The present paper first identified the taxes and fees paid and subsidies received by urban and rural households in 1988, 1995 and 2002. It shows that distortions resulting from policies allowed urban households to escape most of the direct tax burden, because of both a high income tax threshold and poor enforcement. These urban households also received subsidies. The data also show that the rural population paid tax, although they received 
very little in terms of either private transfers or public services at the national or local level. The models confirmed these findings and support the hypothesis that a system of regressive taxation and subsidy existed in China. The decomposition reveals that these policies have contributed to the persistent and widening urban-rural income gap.

China has also imposed barriers to freedom of movement for rural workers, although migration has historically helped to reduce inequality between rural and urban populations. Taxes and subsidies are based on individual Hukou status determined largely by place of birth. Even when rural laborers migrate to urban areas, they still faced rural tax and fee liabilities simply because of their rural Hukou status. This situation was exacerbated by the huge discrimination in terms of occupational attainment and wages for migrant workers.

In 2006, the agricultural tax plus many fees and administrative charges were removed by the central government. Although there are still some fees imposed by local governments, the burden on rural households has been greatly reduced. It would be interesting to compare the welfare status of households before and after the abolishment of the agricultural tax, however, lack of recent data preclude such investigation. Future research needs to be undertaken to address this question when new micro-level data are available.

Wide ranging reforms in China have led to high levels of economic growth but this has resulted in increasing income inequality and discrimination. At the current stage of development, a major objective of the national social benefit system should be to reduce income inequality. The present paper has shown that the tax system has improved during the reforms and the differential in the tax burden between rural and urban households is slowly decreasing.

However, the urban-rural income gap is still increasing, primarily because of the increasing role of the market in allocating wages. Tax system reform cannot improve the earning capacity of those who were previously disadvantaged. More should be done to provide more opportunities for rural laborers, such as eliminating the barriers to migration, improving the infrastructure in rural areas and reducing the obstacles for preventing rural residents migrating to urban areas to compete fairly in an integrated labor market.

\section{References}

Bernstein, Thomas and Xiaobo Lu, 2000, "Taxation without representation: Peasants, the central and local states in reform in China," The China Quarterly, Vol. 163, pp. 742-63.

Chang, Gene H., 2002, "The cause and cure of China's widening income disparity," China Economic Review, Vol. 13, No. 4, pp. 335-40.

Chen, Xiwen, 2009, "Review of China's agricultural and rural development: Policy changes and current issues," China Agricultural Economic Review, Vol. 1, No. 2, pp. 121-35.

(C) 2010 The Authors

China \& World Economy (C2010 Institute of World Economics and Politics, Chinese Academy of Social Sciences 
Gao, Qin, 2006, "The social benefit system in urban China: Reforms and trends from 1988 to 2002," Journal of East Asian Studies, Vol. 6, No. 1, pp. 31-67.

Griffin Keith and Renwei Zhao, eds, 1993, The Distribution of Income in China, NY: St. Martins Press.

Gustafsson, Bjorn and Shi Li, 1997, "Types of income and inequality in China at the end of the 1980s," Review of Income and Wealth, Vol. 43, No. 2, pp. 211-26.

Gustafsson, Björn, Shi Li and Terry Sicular, eds, 2008, Income Inequality and Public Policy in China, New York: Cambridge University Press.

Knight, John and Lina Song, 1999, The Rural-Urban Divide: Economic Disparities and Interactions in China, Oxford: Oxford University Press.

Lin, Justin Yifu, Fang Cai and Zhou Li, 1996, The China Miracle: Development Strategy and Economic Reform, Hong Kong: Hong Kong Chinese University Press.

Lu, Mai and Calla Wiemer, 2005, “An end to China's agriculture tax," China: An International Journal, Vol. 3, No. 2, pp. 320-30.

Mirrlees, James, 1971, "An exploration in the theory of optimum income taxation," Review of Economic Studies, Vol. 38, No. 2, pp. 175-208.

Musgrave, Richard, 1994, "Progressive taxation, equity, and tax design," in Joel Slemrod, ed., Tax Progressivity and Income Inequality, Cambridge: Cambridge University Press, pp. 341-56.

NBS (National Bureau of Statistics of China), 1978-2005, 2009, China Statistical Yearbook, various years, Beijing: China Statistics Press.

Riskin, Carl, Renwei Zhao and Shi Li, eds, 2001, China's Retreat from Equality: Income Distribution and Economic Transition, Armonk, NY: M. E. Sharpe.

Salanie, Bernard, 2003, The Economics of Taxation, Cambridge, MA: MIT Press.

Shorrocks, Anthony, 1984, "Inequality decomposition by population subgroups," Econometrica, Vol. 52, No. 6, pp. 1369-85.

Shorrocks, Anthony and Guanghua Wan, 2005, "Spatial decomposition of inequality," Journal of Economic Geography, Vol. 5, No. 1, pp. 59-81.

Sicular, Terry, Ximing Yue, Björn Gustafsson and Shi Li, 2007, "The urban-rural income gap and inequality in China," Review of Income and Wealth, Vol. 53, No. 1, pp. 93-126.

Slemrod, Joel, 1994, "Introduction" in Joel Slemrod ed., Tax Progressivity and Income Inequality, Cambridge: Cambridge University Press, pp. 1-8.

Slemrod, Joel, 2006, "The consequences of taxation," Social Philosophy and Policy, Vol. 23, No. 2, pp. 73-87.

Tao, Ran and Mingxing Liu, 2005, "Urban and rural household taxation in China: Measurement, comparison and policy implications," Journal of the Asia Pacific Economy, Vol. 10, No. 4, pp. 485-505.

Vickrey, William, 1947, Agenda for Progressive Taxation, New York: The Ronald Press.

Vickrey, William, 1992, “An updated agenda for progressive taxation” American Economic Review, Vol. 82, No. 2, pp. 257-62.

(Edited by Zhinan Zhang) 